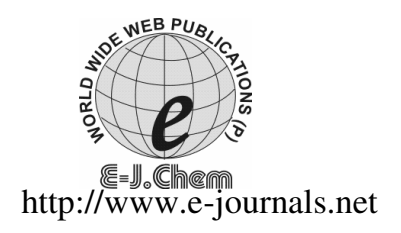

ISSN: 0973-4945; CODEN ECJHAO

E-Journal of Chemistry 2012, 9(1), 487-495

\title{
Corrosion Inhibition Studies of Mild Steel in Acid Medium Using Musa Acuminata Fruit Peel Extract
}

\author{
N. GUNAVATHY and S. C. MURUGAVEL* \\ Department of Chemistry, Nirmala College for Women, Coimbatore, India \\ *Department of Chemistry, PSG College of Technology, Coimbatore, India \\ psgmvel@yahoo.co.in
}

Received 25 April 2011; Revised 23 July 2011; Accepted 30 July 2011

\begin{abstract}
The inhibition effect of unripe fruit peel extract of Musa acuminata (Cultivar variety - Nendran) (MNP) on corrosion of mild steel in $1 \mathrm{~N} \mathrm{HCl}$ has been investigated by weight loss and electrochemical impedance spectroscopy (EIS) with various concentrations of the extract. The effect of temperature on the corrosion inhibition of mild steel in the temperature range of $30^{\circ} \mathrm{C}-80^{\circ} \mathrm{C}$ was carried out. The results indicate that MNP extract act as an effective inhibitor in the acid environment and is of mixed type inhibitor having efficiency as high as $96 \%$ at $2 \%$ inhibitor concentration. The inhibition efficiency of MNP extract increases with the increase of concentration but decreases with the increase in temperature. The inhibitor achieves its inhibition by physical adsorption of nutrients of the peel extract on the surface of the mild steel. The experimental data revealed that the adsorption occurred according to the Langmuir and Temkin adsorption isotherm.
\end{abstract}

Keywords: Plant extract, Corrosion inhibitor, Mild steel, Weight loss, Potentiodynamic Polarization, Adsorption.

\section{Introduction}

An antique fruit crop of the world, known as 'Apple of the paradise' botanically named as Musa acuminata (Nendran), cheapest and plentiful fruit, used widely as food without apparent toxic effect, having antimicrobial and antioxidant activity contains starch, fructosans, phenolic acids, anthocyanins, terpenoids, sterols, polyphenols, gallocatechin and dopamine $e^{1-5}$. The peel of the fruit contains beta sitosterol, stigmasterol, campesterol, cycloeucalenol, cycloartanol and 24-methylene cycloartanol ${ }^{6,7}$. The natural flavonoid present in banana exhibits an antioxidative activity that stops oxidation and corrosion, the deterioration process and discoloration ${ }^{8}$. 
Corrosion is gradual destruction of a material because of its reaction with environment. Both direct and indirect losses due to corrosion are huge. The control of corrosion is thus primarily an economic problem. Corrosion inhibitors reduce the rate of either anodic oxidation or cathodic reduction or both ${ }^{9,10}$.

An attempt to find corrosion inhibitors that are environmentally safe and readily available has been a growing trend in the use of natural products such as leaves, seeds, flowers and fruits extract as corrosion inhibitors for metals in acid cleaning processes ${ }^{11-13}$. Several natural products like Bauhinia purpurea ${ }^{14}$ (leaves), Uncaria gambir $^{8}$ (plant), Azadirachta indica ${ }^{15}$ (leaves, seeds, roots), Aloe vera ${ }^{16}$ (leaves), Phyllanthus amarus ${ }^{17}$ (leaves and seeds), Occimum viridis ${ }^{18}$, Zenthoxylum-alatum ${ }^{19,20}$ (fruit), Musa sapientum ${ }^{21}$ (peel), Green tea ${ }^{22}$ (leaves), Theobroma cacao, Cola acuminata ${ }^{23}$ (leaves), Hibiscus sabdariffa ${ }^{24}$, Oxandra asbeckii ${ }^{25}$ and Citrus paradisi ${ }^{26}$ (juice) were reported as effective corrosion inhibitors in acid medium.

The banana fruit Nendran also called as French plantain, a popular variety in Kerala, India, is relished as a fruit as well as used for preparing juice, healthy food powder, chips etc. Matured fruit slices are made into chips by frying in edible oil after dipping in brine, while the peels are used as fodder for the cattle. The present study makes use of the fruit peels which are available in plenty.

The study examines the action of unripe Musa acuminata fruit peel extract as corrosion inhibitor of mild steel in acid medium with various concentrations and temperature. The kinetics of corrosion of mild steel in acid medium has been identified by weight loss and electrochemical impedance spectroscopy methods.

\section{Experimental}

\section{Inhibitor preparation}

The peels of Musa acuminata fruit were collected from the chips manufacturing shops of Coimbatore city, dried and powdered. About $12.5 \mathrm{~g}$ of the powder was refluxed with 250 $\mathrm{mL}$ of $1 \mathrm{~N} \mathrm{HCl}$ for about 3 hours and was allowed to stand overnight. The resultant solution was filtered and the filtrate was made up to $250 \mathrm{~mL}$. From this $5 \%$ stock solution of the extract, different concentrations of the inhibitor solution like $0.005,0.01,0.05,0.10,0.50$, $1.0,1.5$, and $2.0 \% \mathrm{v} / \mathrm{v}$ were prepared.

\section{Specimen preparation}

For weight loss method mild steel coupons of dimension $1 \times 5 \times 0.2 \mathrm{~cm}$ with a small hole on the upper part to facilitate suspension of the coupons in the test solutions were used. The specimens were degreased with acetone and pickled with concentrated hydrochloric acid. The surface of the specimens were mechanically polished using SiC emery papers of grades 400 and 600, washed with distilled water, dried at room temperature and stored in a desiccator.

For electrochemical polarization and impendence measurements mild steel rod of $15 \mathrm{x}$ $0.5 \mathrm{~cm}$ were used. These rods were mechanically polished using different grades of $\mathrm{SiC}$ emery paper, repeatedly rinsed with distilled water and dried before use.

\section{Weight loss method}

\section{Effect of concentration}

The prepared specimens in duplicate were suspended from glass hook in $100 \mathrm{~mL}$ of the test solution, with and without the extracts of different concentration for 1, 2, 3, 4, 5, 6, 7, 12 and $24 \mathrm{~h}$ at room temperature. The weight of the specimens before and after immersion was 
determined using an analytical balance of $0.0001 \mathrm{mg}$ accuracy. Inhibition efficiency of the mild steel was determined using the average of the duplicate value using the relation

$$
\mathrm{IE} \%=\frac{\mathrm{W}_{1}-\mathrm{W}_{2}}{\mathrm{~W}_{1}} \times 100
$$

Where, $\mathrm{W}_{1}$ and $\mathrm{W}_{2}$ are weight loss of the mild steel without and with the inhibitor respectively.

\section{Effect of temperature}

The polished and pre-weighed specimens in duplicate were suspended in $100 \mathrm{~mL}$ of the test solution without and with the addition of different concentrations of the peel extract for $1 \mathrm{~h}$ in the temperature range of $30-80{ }^{\circ} \mathrm{C}$ using thermostat. After the corrosion test, the specimens were washed with distilled water, dried and weighed. From the weight loss the inhibition efficiency (IE \%) was calculated.

\section{Electrochemical measurements}

A three electrode cell assembly of borosil glass consisting of a mild steel rod of size 15 $\mathrm{X} 0.5 \mathrm{~cm}$ as working electrode (WE), a large area platinum mesh of negligible impedance as counter electrode (CE), and a saturated calomel electrode as reference electrode (RE) containing $100 \mathrm{~mL}$ of the test solution was used for electrochemical measurements at $30{ }^{\circ} \mathrm{C}$.

\section{Potentiodynamic polarization studies}

Potentiodynamic polarization studies were done using computer controlled PARSTAT 2273 - Advanced Electrochemical System. Before recording the polarization curves the mild steel rod as a working electrode was immersed in the test solution for 10 minutes to reach saturation. The potential was changed with the speed of $2 \mathrm{MHz}$ to $100 \mathrm{mHz} \mathrm{min}^{-1}$. From polarization measurement, the corrosion current $\left(\mathrm{I}_{\text {corr }}\right)$, corrosion potential $\left(\mathrm{E}_{\text {corr }}\right)$ and anodic (ba) and cathodic (bc) Tafel slopes were determined. The percentage inhibition efficiency ( ) was calculated from,

$$
\eta=\frac{I_{\text {corr }}-I_{\text {corr (inh) }}}{I_{\text {corr }}} \times 100
$$

Where, $\mathrm{I}_{\text {corr }}$ and $\mathrm{I}_{\text {corr (inh) }}$ are corrosion current density without and with inhibitor respectively.

\section{Electrochemical impendence spectroscopy (EIS)}

EIS study enables us to understand the various processes that take place on the metalelectrolyte solution interface, adsorption-desorption of the reaction intermediates. The Nyquist plots are obtained by measuring AC impedance and Tafel plot using polarization data. The EIS experiments were conducted using the same setup as used in the polarization method using frequency range $2 \mathrm{MHz}$ to $100 \mathrm{mHz}$ with $\mathrm{AC}$ amplitude of $10 \mathrm{mv}$. The real $\left(Z^{\prime}\right)$ and imaginary $\left(Z^{\prime \prime}\right)$ impedance values were measured for various frequencies. The charge transfer resistance values $\left(R_{c t}\right)$ obtained by plotting $Z^{\prime} v s . Z^{\prime \prime}$ were used to calculate the percentage inhibition efficiency from

$$
\mathrm{IE} \%=\frac{\mathrm{R}_{\mathrm{ct}}{ }^{0}-\mathrm{R}_{\mathrm{ct}}}{\mathrm{R}_{\mathrm{ct}}{ }^{0}} \times 100
$$

Where, $\mathrm{R}_{\mathrm{ct}}$ and $\mathrm{R}_{\mathrm{ct}}{ }^{0}$ are charge transfer resistance values with and without inhibitor. 


\section{Results and Discussion}

\section{Weight loss method-effect of concentration}

The inhibition efficiency of mild steel exposed to different concentration of MNP extract in $1 \mathrm{~N} \mathrm{HCl}$ at various immersion periods at $30{ }^{\circ} \mathrm{C}$ are presented in the Table 1 and Figure 1. The corrosion inhibition efficiency increased with the increase in concentration of the peel extract ${ }^{13}$. Maximum efficiency of $96.08 \%$ was achieved with $2 \%$ of MNP extract at 5 hours of immersion at $30^{\circ} \mathrm{C}$. The increase in inhibition efficiency may be attributed to the increase in number of adsorption of nutrients on the surface of mild steel which makes a barrier for mass and charge transfer and prevent further corrosion ${ }^{12}$.

Table 1. IE \% of MNP extract on mild steel in $1 \mathrm{~N} \mathrm{HCl}$ at different concentration and different immersion periods

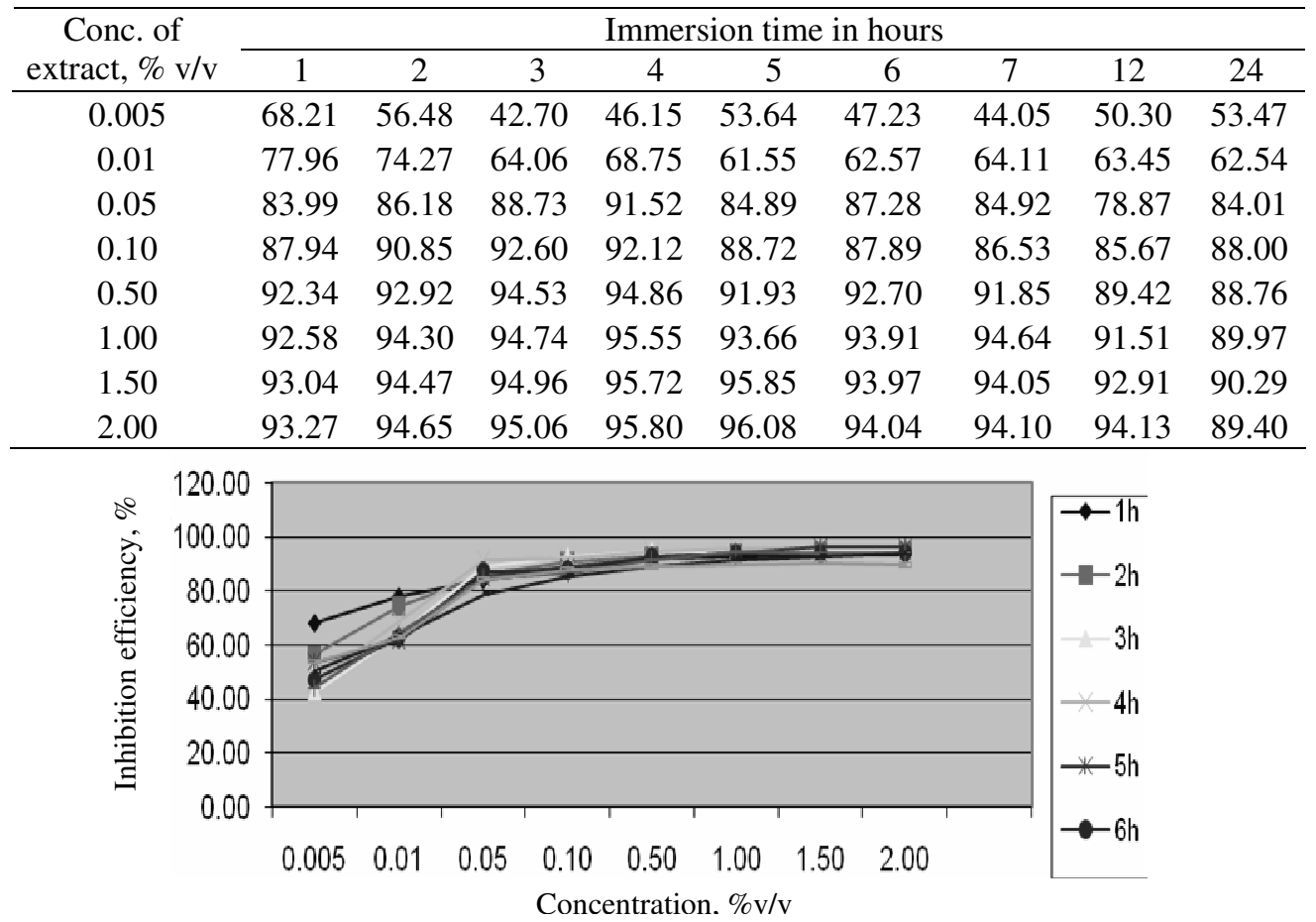

Figure 1. Variation of Inhibition efficiency of mild steel with various concentrations of $\mathrm{MNP}$ extract in $1 \mathrm{~N} \mathrm{HCl}$

\section{Effect of immersion time}

Inhibition efficiency of peel extract on mild steel is influenced by the immersion time. Inhibition efficiency of $93.27 \%$ was obtained for MNP extract for immersion period of 1 hour at $2 \% \mathrm{v} / \mathrm{v}$ concentration. At 3, 5 and $7 \mathrm{~h}$ the maximum efficiency of $95.06 \%, 96.08 \%$ and $94.10 \%$ respectively were obtained for $2 \%$ v/v MNP extract (Table 1 and Figure 2). The variation in inhibition efficiency with increasing time may be due to the shift in adsorption and desorption equilibrium which takes place as the exposure time increases.

\section{Effect of temperature}

To study the effect of temperature on the corrosion inhibition properties of peel extract, experiments were carried out in absence and presence of varying concentration of the inhibitor 
in the temperature range from $30-80{ }^{\circ} \mathrm{C}$. The results are summarized in Table 2 and Figure 3 . The data indicated that the peel extract was effective up to $40{ }^{\circ} \mathrm{C}$ and decreased slightly thereafter.

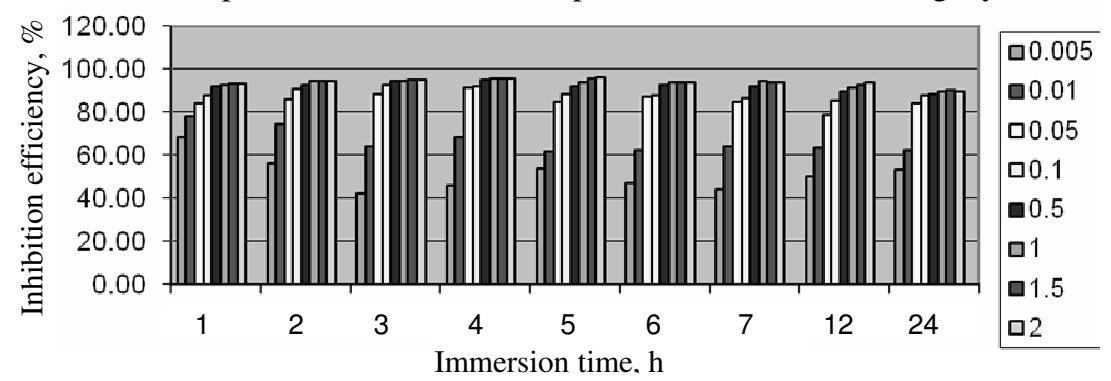

Figure 2. Influence of immersion time on inhibition efficiency of mild steel in various concentrations of MNP extract in $1 \mathrm{~N} \mathrm{HCl}$

Table 2. Effect of temperature on mild steel corrosion in $1 \mathrm{~N} \mathrm{HCl}$ in absence and presence of MNP extract

\begin{tabular}{ccccccc}
\hline Conc of & \multicolumn{7}{c}{ Temperature, $\mathrm{K}$} \\
\cline { 2 - 7 } extract, \% v/v & 303 & 313 & 323 & 333 & 343 & 353 \\
\hline 0.005 & 68.37 & 58.92 & 36.56 & 37.67 & 67.93 & 16.29 \\
0.01 & 77.07 & 65.00 & 50.68 & 54.84 & 72.73 & 18.47 \\
0.05 & 78.77 & 83.95 & 83.58 & 78.68 & 78.28 & 60.83 \\
0.10 & 85.35 & 88.14 & 88.32 & 84.57 & 79.84 & 70.84 \\
0.50 & 91.08 & 94.82 & 92.40 & 92.26 & 90.80 & 80.08 \\
1.00 & 93.21 & 95.61 & 94.37 & 94.68 & 91.32 & 85.64 \\
1.50 & 93.42 & 96.01 & 95.26 & 94.73 & 93.76 & 84.73 \\
2.00 & 95.75 & 96.91 & 95.78 & 95.16 & 94.61 & 86.42 \\
\hline
\end{tabular}

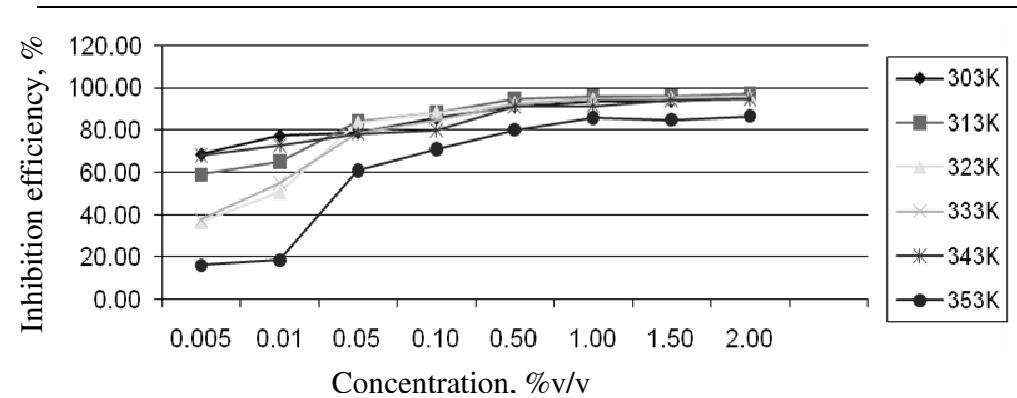

Figure 3. Effect of temperature on mild steel in $1 \mathrm{~N} \mathrm{HCl}$ in presence and absence of MNP extract

The maximum efficiency of $96.91 \%$ at $40^{\circ} \mathrm{C}$ indicates that the inhibitor can be effectively used up to $40{ }^{\circ} \mathrm{C}$. The decrease in inhibition efficiency with increase in temperature may be due to desorption of inhibitor molecules at faster rate at higher temperature ${ }^{13,27}$.

\section{Effect of surface coverage}

The surface coverage $\theta$ of the inhibitor at different concentrations was calculated using the equation,

$$
\theta=\left(1-C_{R} / C_{R}{ }^{\prime}\right)
$$


Where, $C_{R}$ and $C_{R}{ }^{\prime}$ are the corrosion rate with and without inhibitor respectively obtained from the weight loss method.

The surface coverage increased with increase in the concentrations of extract. This may be due to increased number of inhibitor molecules getting parallely adsorbed on the surface of mild steel ${ }^{26}$.

\section{Adsorption isotherm}

The mechanism of corrosion inhibition and degree of adsorption of inhibitor depend on the chemical structure of the molecule, chemical composition of the solution, the nature of metal surface, the temperature and the electrochemical potential at the metal / solution interface. The surface coverage $(\theta)$ values help in understanding adsorption characteristics. The $\theta$ values for different concentrations of the extract were tested by fitting various isotherms such as Langmuir and Temkin.

Straight line obtained by plotting $\log (\theta / 1-\theta) v s . \log C$ (Langmuir adsorption) (Figure 4) and $\theta v s . \log C$ (Temkin adsorption) (Figure 5) indicated that the process of inhibition is due to physical adsorption ${ }^{13,27,28}$.

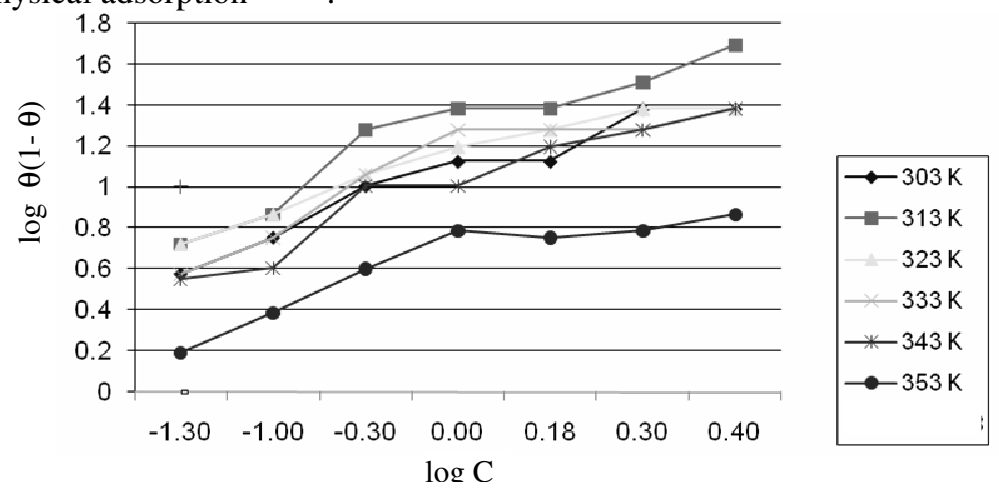

Figure 4. Langmuir adsorption isotherm of MNP extract on mild steel in $1 \mathrm{~N} \mathrm{HCl}$ at various temperature

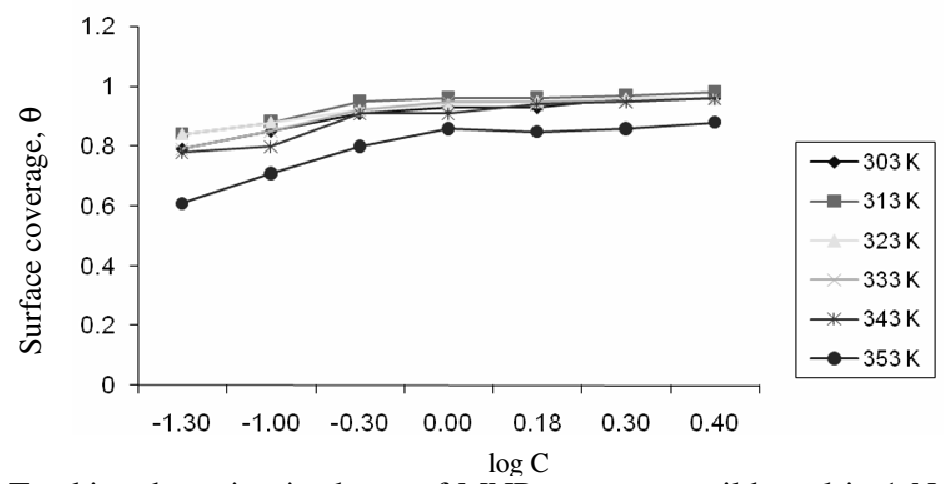

Figure 5. Temkin adsorption isotherm of MNP extract on mild steel in $1 \mathrm{~N} \mathrm{HCl}$ at various temperature

\section{Electrochemical method}

\section{Potentiodynamic polarization studies}

The effect of the extract on the electrochemical behaviour of mild steel was studied by carrying out cathodic and anodic polarization experiments. The electrodynamic parameters 
of the inhibitor such as corrosion potential $\mathrm{E}_{\text {corr }}$, corrosion current density $\mathrm{I}_{\text {corr }}$, anodic and cathodic Tafel slopes, $b_{a}$ and $b_{c}$, in absence and presence of inhibitor are listed in Table 3 and depicted in Figure 6. Further the result reveals that $I_{\text {corr }}$ values of acid in presence of inhibitor are lower than that of acid in absence of inhibitor indicating that increase in inhibition property was due to adsorption of inhibitor molecules on the electrode surface. This shows that the peel extract of Musa acuminata in $1 \mathrm{~N} \mathrm{HCl}$ acts as very good corrosion inhibitor for mild steel. The steady value of $\mathrm{E}_{\text {corr }}$ suggest that the inhibitor is mixed type inhibitor and this infers that the inhibitor reduces the hydrogen evolution and anodic dissolution of mild steel ${ }^{25,29}$.

Table 3. Potentiodynamic polarization parameters for mild steel in $1 \mathrm{~N} \mathrm{HCl}$ in the absence and presence of MNP extract

\begin{tabular}{|c|c|c|c|c|c|c|c|}
\hline Conc & $-\mathrm{E}_{\text {corr }}$ & $\mathrm{I}_{\text {corr }}$ & $\mathrm{b}_{\mathrm{c}}$ & $\mathrm{b}_{\mathrm{a}}$ & $\mathrm{Rp}$ & \multicolumn{2}{|c|}{$\%$ IE } \\
\hline$\% \mathrm{v} / \mathrm{v}$ & $\mathrm{V}$ & $\mathrm{mAmp} / \mathrm{cm}^{2}$ & $\mathrm{mV} / \mathrm{dec}$ & $\mathrm{mV} / \mathrm{dec}$ & $\mathrm{Ohm} \mathrm{cm}^{2}$ & Tafel & Linear \\
\hline Blank & 0.463 & 7831.0 & 774.19 & 317.84 & 8.204 & - & - \\
\hline 0.005 & 0.455 & 2439.0 & 244.47 & 161.70 & 8.342 & 68.86 & 1.65 \\
\hline 0.01 & 0.454 & 1235.0 & 219.13 & 121.99 & 8.948 & 84.23 & 8.31 \\
\hline 0.10 & 0.464 & 118.7 & 170.84 & 101.56 & 18.010 & 98.48 & 54.45 \\
\hline 0.50 & 0.466 & 124.8 & 196.33 & 75.57 & 18.651 & 98.41 & 56.01 \\
\hline 1.00 & 0.459 & 130.1 & 191.83 & 68.18 & 20.283 & 98.34 & 59.55 \\
\hline 1.50 & 0.468 & 64.1 & 176.57 & 71.79 & 26.503 & 99.18 & 69.05 \\
\hline 2.00 & 0.472 & 65.7 & 167.35 & 77.64 & 26.526 & 99.16 & 69.07 \\
\hline
\end{tabular}

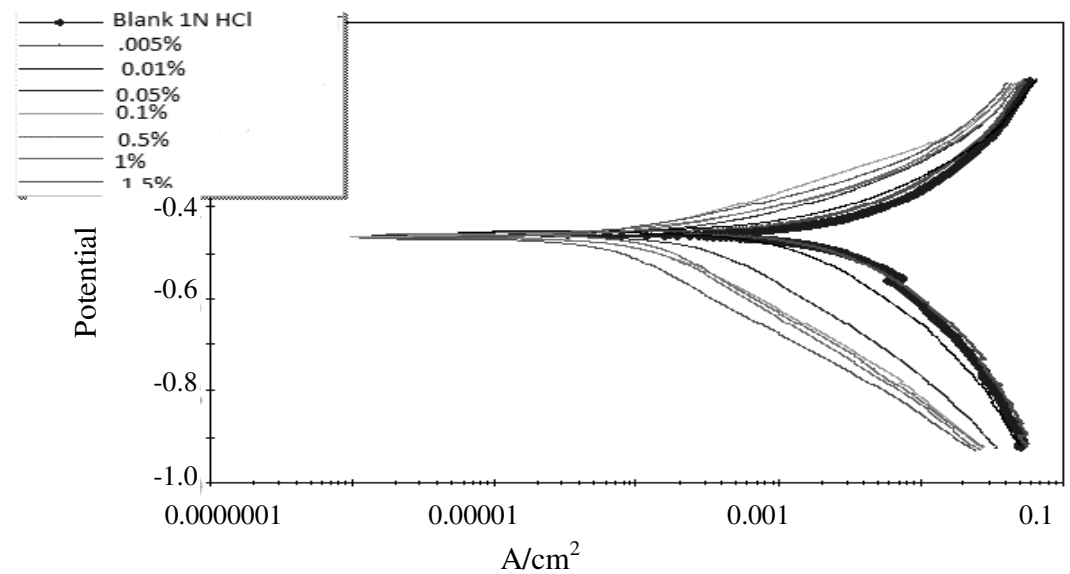

Figure 6. Potentiodynamic polarization curves for mild steel in $1 \mathrm{~N} \mathrm{HCl}$ without and with different concentrations of MNP extract

\section{Electrochemical Impedance studies (EIS)}

The corrosion behaviour of mild steel in $1 \mathrm{~N} \mathrm{HCl}$ in presence of MNP was also studied using EIS at $30{ }^{\circ} \mathrm{C}$. The impedance parameters like charge transfer resistance $\left(\mathrm{R}_{\mathrm{ct}}\right)$, double layer capacitance $\left(\mathrm{C}_{\mathrm{dl}}\right)$ and the corresponding inhibition efficiency are determined.

It is clear from the Table 4 and Figure 7 that $C_{\mathrm{dl}}$ values decreased with increase in concentration of the inhibitor which can result from decrease in dielectric constant due to adsorption of molecules of the extract on the surface of the metal ${ }^{12}$. The $\mathrm{R}_{\mathrm{ct}}$ values increase 
with increase in the concentration of the inhibitor which are in accordance with the results obtained by weight loss method ${ }^{30}$.

Table 4. EIS parameters for the corrosion of mild steel in $1 \mathrm{~N} \mathrm{HCl}$ containing MNP extract at $30^{\circ} \mathrm{C}$

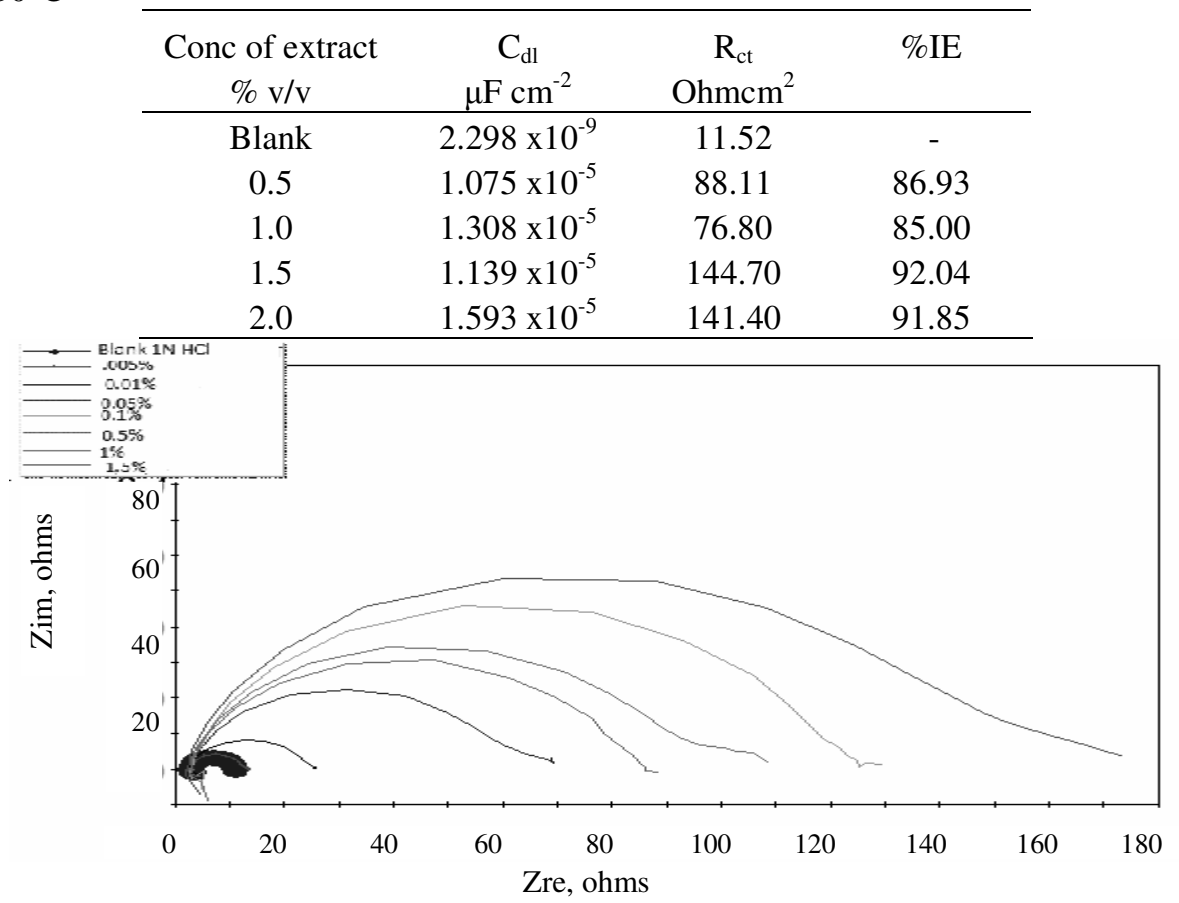

Figure 7. Impedance plots recorded for mild steel in $1 \mathrm{~N} \mathrm{HCl}$ solutions without and with various concentrations of MNP extract

\section{Corrosion inhibition mechanism}

The peel extract of Musa acuminata (MNP) provides corrosion inhibition for mild steel by adsorption of the nutrients present in the extract which act as inhibitor molecules on the active sites on the metal surface. This is evident from Temkin adsorption isotherm where surface coverage $(\theta)$ is plotted against $\log \mathrm{C}$. The plant nutrients sitosterol, stigmasterol, campesterol, cycloeucalenol, cycloartanol, and 24-methylene cycloartanol have either nitrogen or oxygen or both and pair of electrons in nitrogen and oxygen can facilitate the adsorption of the nutrients of the extract on metals. Interaction between the $\pi$ electrons of oxygen and the vacant $d$ orbital of the metal surface may also be another possibility for adsorption and for inhibition ${ }^{31,32}$.

\section{Conclusions}

The peel extract of Musa acuminata was found to be effective inhibitor at concentration of $2 \% \mathrm{v} / \mathrm{v}$ in $1 \mathrm{~N} \mathrm{HCl}$ solution. The inhibition efficiency of mild steel in $1 \mathrm{~N} \mathrm{HCl}$ increases with increasing the concentration of MNP extract. The performance of the extract as corrosion inhibitor decreased with increasing temperature. AC impendence plots of mild steel in the acid medium show that polarization resistance increases with the increase of extract concentration. The results indicate that inhibition effect of the plant extract was due to physical adsorption of the nutrients present in the extract onto the active sites on the surface of the metal. 


\section{Acknowledgement}

The authors are grateful to the Principal, Nirmala College for Women, (Autonomous), Coimbatore and Principal, PSG College of Technology, Coimbatore, for the constant support and for providing the necessary facilities for this research work.

\section{References}

1. Radha T and Mathew L, Fruit Crops; Peter K V (Ed): Horticulture Science Series, New India Publishing Agency, New Delhi, Chapter 4, 2007, 3, 33 - 37.

2. William Charles Evans, Trease and Evans Pharmacognosy, W B Saunders, New York, 2002, 555- 560.

3. Matook Saif Mokbel and Fumio Hashinaga, Am J Biochem Biotechnol., 2005, 1(3), 125 -131.

4. Shinichi Someya, Yumiko Yoshiki and Kazuyoshi Okubo, Food Chem., 2002, 79(3), 351-351.

5. Rafaela Gonzalez-Montelongo, Gloria Lobo M and Monica Gonzalez, Food Chem., 2010, 119(3), 1030-1039.

6. Anhwange B A, J Food Technol., 2008, 6(6), 263-266.

7. Knapp F F and Nicholas H J, Phytochem., 1969, 8(1), 207-214.

8. Mohd. Hazwan Hussin and Mohd Jain Kassim, J Phys Sci., 2010, 1(1), 1-13.

9. Mars G Fontana, Corrosion Engineering ( $3^{\text {rd }}$ Ed), Tata Mc Graw - Hill, Education Private Limited, New Delhi, 2010, 1-9.

10. Raj Narayan, An introduction to metallic corrosion and its prevention, Oxford and IBH Publishing Co, New Delhi, 1983, 1-6.

11. Saleh R M, Ismail A A and El Hosary A A, Corros Sci., 1983, 23(11), 1239-1241.

12. Fabrizio Zucchi and Ibrahim Hashi Omar, Surf Technol., 1985, 24(4), 391-399.

13. Janaina Cardozo da Rocha, Jose Antonio da Cunha Ponciano Gomes and Eliane D'Elia, Corros Sci., 2010, 52(7), 2341-2348.

14. Patel N S, Jauhari S and Mehta G N, The Arabian J Sci Eng., 2009, 34(2C), 61-69.

15. Peter C Okafor, Eno E Ebenso and Udofot J Ekpe, Int J Electrochem Sci., 2010, 5, 978-993.

16. Eddy N O and Odoemelam S A, Pigment Resin Technol., 2009, 38(2), 111-115.

17. Olusegun K Abiola, Otaigbe J O E, Corros Sci., 2009, 51(11), 2790-2793.

18. Emeka E Oguzie, Mater Chem Phys., 2006, 99(2-3), 441-446.

19. Gunasekaran G and Chauhan L R,, Electrochimica Acta, 2004, 49, 4387-4395.

20. Chauhan L R and Gunasekaran G, Corros Sci., 2007, 49(3), 1143-1161.

21. Eddy N O, Ebenso E E, African J Pure Appl Chem., 2008, 2(6), 46-54.

22. Sheyreese M. Vincent et Cyril B Okhio, The J Corros Sci Eng., 2005, 7(36), 1-10.

23. Umoru L E, Fawehinwi I A and Fasasi A Y, J Appl Sci Res., 2006, 2(4), 200-204.

24. Emeka E Oguzie, Portugaliae Electrochimica Acta, 2008, 26, 303-314.

25. Lebrini M, Robert F, Lecante A, Roos C, Corros Sci., 2011, 53(2), 687-695.

26. Olusegun A K, Oforka N C and Ebenso E E, J Corros Sci Eng., 2004, 8(5), 1-5.

27. Ashish Kumar Singh and Quraishi M A, Corros Sci., 2011, 53(4), 1288-1297.

28. Halambek J, Berkovic K and Vorkapic Furac J, Corros Sci., 2010, 52(12), 978-3983.

29. Sudhish Kumar, Shukla and Quraishi M A, J Appl Electrochem., 2009, 39(9),1517- 1523.

30. XueHui Pang, WenJuan Guo, WeiHua Li, Jian Dong Xie and Bao Ronja Hau, Science in China Series B Chemistry, 2008, 51(10), 928-936.

31. Poongothai $\mathrm{N}$, Ramachanderen $\mathrm{T}$, Natesan $\mathrm{M}$ and Murugavel $\mathrm{S} \mathrm{C}, \mathrm{NACE}$ International, Material Performance, 2010, 49(4), 50-55.

32. Poongothai N, Ramachanderen T, Natesan M and Murugavel S C, Material Performance, 2009, 2-6. 


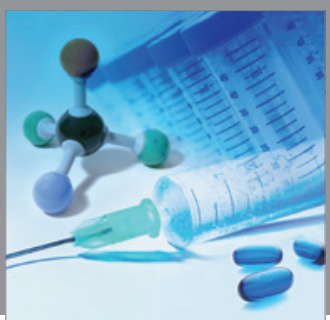

International Journal of

Medicinal Chemistry

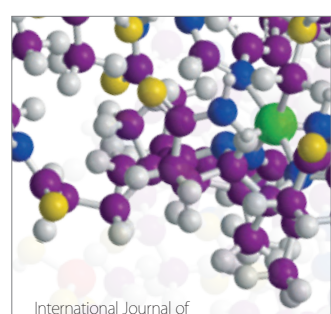

Carbohydrate Chemistry

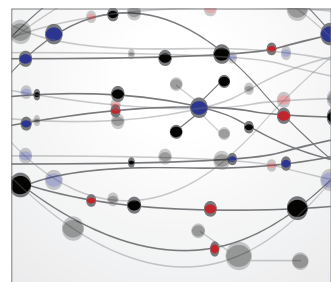

The Scientific World Journal
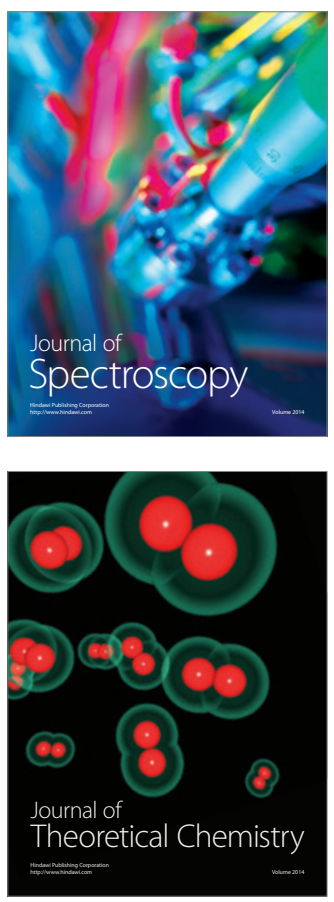
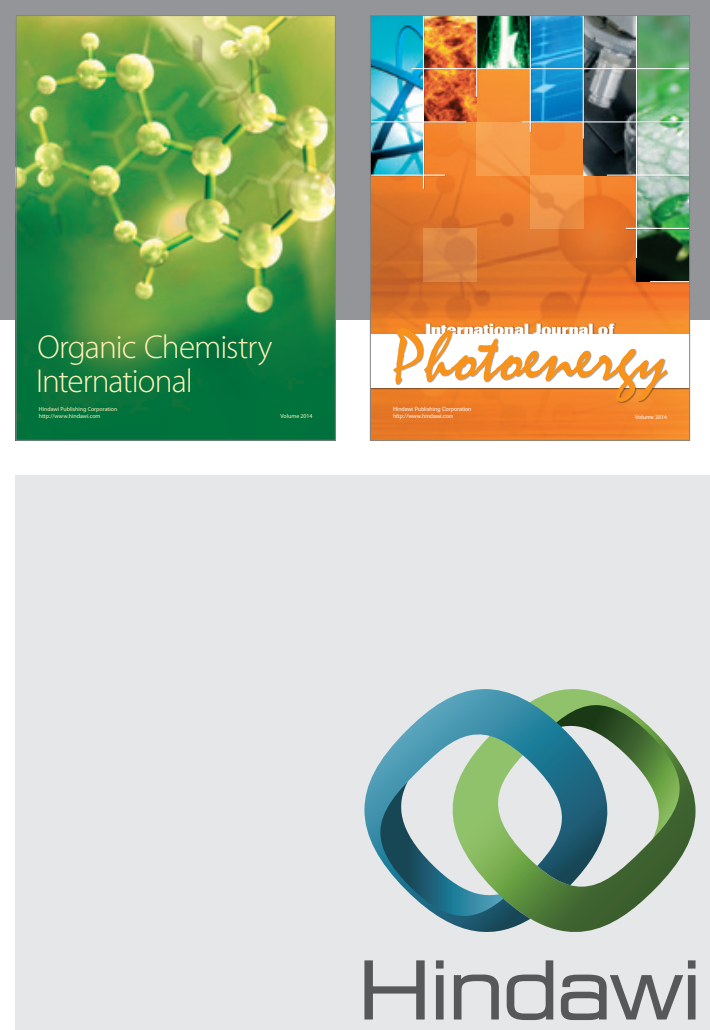

Submit your manuscripts at

http://www.hindawi.com
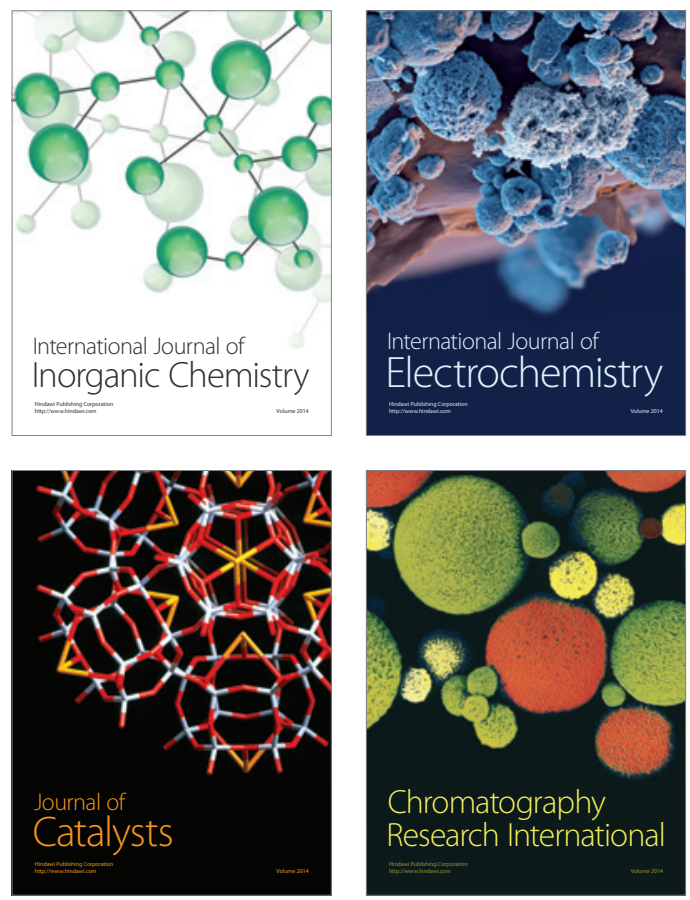
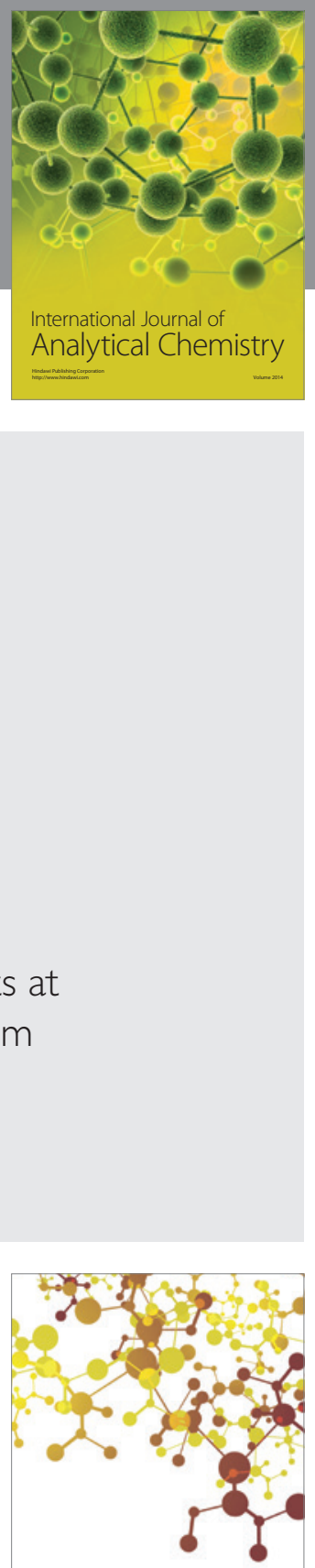

Journal of

Applied Chemistry
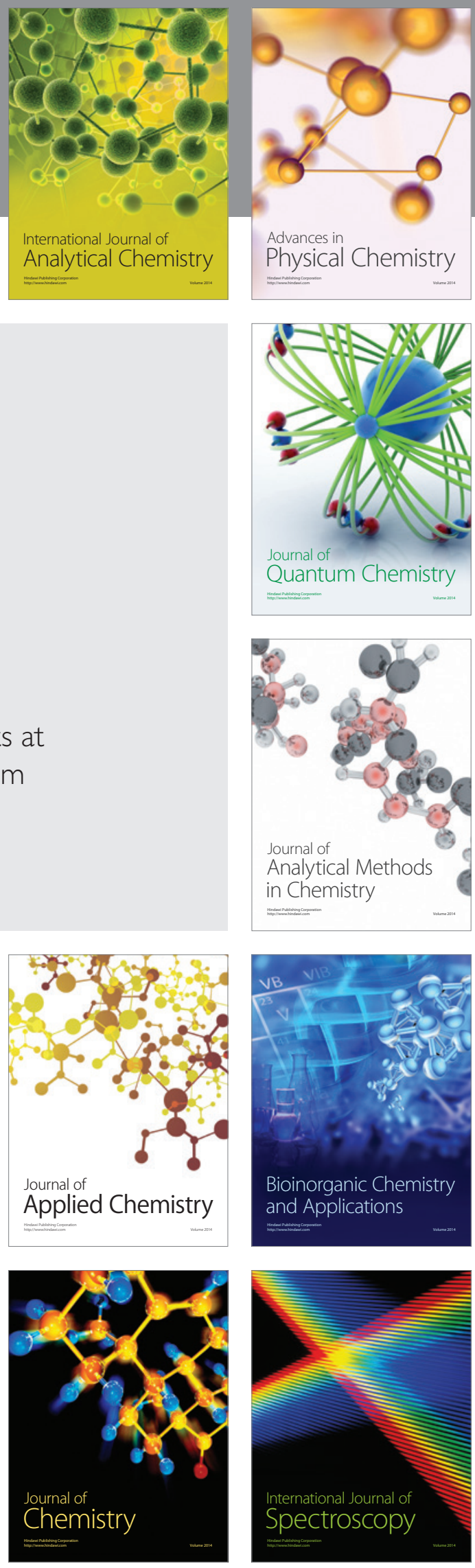